\title{
We are in this Together: Retrospective Parentification, Sibling Relationships, and Self-Esteem
}

\author{
Judyta Borchet $\mathbb{D}^{1} \cdot$ Aleksandra Lewandowska-Walter ${ }^{1} \cdot$ Piotr Połomski $^{1} \cdot$ Aleksandra Peplińska $^{1} \cdot$ Lisa M. Hooper $^{2}$
}

Published online: 15 May 2020

(c) The Author(s) 2020

\begin{abstract}
Parentification occurs when children provide caregiving for family members that typically exceeds their capacity and developmental stage. Parentification roles and responsibilities are often linked with deleterious outcomes, including robbing children of age-appropriate opportunities, activities, and support. However, in some circumstances, such as caring for a sibling vs. caring for a parent, parentification may engender feelings of self-efficacy, competence, and other positive outcomes. The primary objective of the current study was to explore the possible benefits of parentification. Using an understudied, international population, the current study tested the benefits of parentification in the context of the sibling relationship. Two research questions guided the study: to what extent are perceived benefits of parentification positively associated with self-esteem among a sample of Polish late adolescents? And to what extent does the quality of the sibling relationship mediate the association between perceived benefits of parentification and self-esteem? Results from the current sample showed the quality of sibling relationships partially mediated the relation between parentification and self-esteem. The findings underline the importance of assessing the quality of sibling relationships when an individual or family presenting for clinical services related to past and current family discord and dysfunction. Future research might consider other factors in the sibling relationship, such as personality, that could relate to positive outcomes from parentification.
\end{abstract}

Keywords Benefits of parentification $\cdot$ Self-esteem $\cdot$ Sibling relationships $\cdot$ Late adolescence $\cdot$ International research

\section{Highlights}

- Children and adolescents who experience parentification may employ various coping mechanisms.

- Quality relationships between siblings may reduce the negative outcomes of parentification.

- International studies on individuals who experience parentification are needed.

- Relationships other than the harmful ones with parents must be investigated.

Although adverse situations in the family system are commonly related to a negative and unstable self-esteem, there are instances when the same situations might facilitate feelings of resiliency, self-efficacy, and competency (ByngHall 2008). One systemic structure that may engender

Judyta Borchet

judyta.borchet@ug.edu.pl

1 University of Gdańsk, Institute of Psychology, Jana Bażyńskiego 4, Gdańsk 80-309, Poland

2 University of Northern Iowa, Center for Educational Transformation, 108 Schindler Education Center, Cedar Falls, IA 50614-0410, USA positive outcomes is when roles are reversed between children and adults, and the hierarchy is inverted in the family system. This structure is commonly characterized as a dysfunctional family system and includes the family system process described as parentification (Minuchin 1974). Paradoxically, parentification, or young caregiving, can result in children experiencing an increase in self-esteem or forming new skills as a result of engaging in adult-like family roles and responsibilities, including caring for a parent or sibling in difficult situations (Schier 2014). A review of the literature suggests the parentified child's future development and the possible outcomes may depend on how the child feels about, and makes meaning of, the parentification experience (Jurkovic 1997). 
Family systems theory undergirds the idea that one pathway between parentification and its related outcomes may be differentiated based on the feelings one has about parentification. Jurkovic (1997) described this as the perceived fairness of parentification and Hooper (2009) describes this as the perceived benefits of parentification. Clinicians and researchers alike contend it is critical to determine how the individual views or assesses her or his roles and situation within the family system, separate and apart from the actual responsibilities performed within the family. For example, if a child sees the advantages of caregiving roles, responsibilities, and relationships, and maintains that view believing in the cultural appropriateness or deriving a sense of self-importance, then those views about the experiences can inform a positive self-evaluation. In addition to the recognition of the perceived benefits of parentification, questions have arisen about what conditions have to be met or what protective factors must be evidenced in the child's life in order for parentification to become a constructive experience (Jurkovic 1997; Schier 2014). The factors that may impinge upon the pathway between parentification and negative and positive valence and outcomes could be (a) to whom the parentification is directed (parent vs. sibling) and (b) the quality of those relationships (Burton et al. 2018; Fitzgerald et al. 2008). Given the ubiquitous nature of parentification in family systems, it is important to consider factors that may exacerbate and/or buffer the commonly evidenced negative outcomes and scantly observed positive outcomes (Byng-Hall 2008).

As defined in family psychology and attachment theory, parentification is a distortion of the division of roles and responsibilities in the family, in which those roles are reversed (Haxhe 2016; Hooper et al. 2008; Jurkovic 1997; Minuchin 1974). This non-normative pattern of interactions in most families, involves children or adolescents engaging in caretaking for their parents (or other family members) rather than the children being cared for by their parents. Children who are charged with taking care of their family members are often robbed of performing their own developmental tasks, as well as activities with their peers. In these cases, family caregiving is often problematic and disruptive to the child's personal development (BoszormenyiNagy and Spark 1973; Hooper et al. 2011; Hooper and Wallace 2010; Mika et al. 1987; Schier 2010, 2014). Parentification takes place in families all over the world, irrespective of the culture of the family in which the child is being raised (Hooper 2014; Shih et al. 2010; Titzmann 2012), and it is related to both negative and positive consequences during adolescence and adulthood (Aldridge and Becker 1993; Carroll and Robinson 2000; Peris et al. 2008; Wells and Jones 2000). In one meta-analysis, adults who had experienced an inverted hierarchy during their childhood were prone to have a higher risk of substance abuse in adulthood (Hooper et al. 2011).
Although less commonly investigated, engaging in the role of a parentified child can facilitate positive outcomes. Additionally, the parentification process can be consonant with cultural expectations in the family, as well as sociodemographic factors, and to whom the caregiving is directed (parent vs. sibling). For example, Burton (2007) suggested parentification may facilitate the development of a sense of responsibility, self-agency, efficiency, and competencies among racially, ethnically, and culturally diverse individuals. Fitzgerald et al. (2008) conducted a study on instrumental parentification, which manifested itself as a form of caregiving for siblings. Their results showed that instrumental parentification was positively associated with psychosocial adaptation. The authors discussed that the increase in the children's competencies gained while engaging in caregiving resulted in their psychosocial adaptation. However, the positive impact of parentification in childhood, and later in adulthood, may depend on individual-level factors (e.g., child's personality and external factors). Williams and Francis (2010) suggested that an internal sense of control is an important protective factor for children against the commonly reported negative consequences of reversing roles within the family. Hooper et al. (2012) found that to a lesser extent, adolescents who carried out caregiving responsibilities within a family, due to the parent's addiction to alcohol, self-reported similar problems, and were much more prone to symptoms of depression. Therefore, parentification may produce both negative and positive outcomes simultaneously and the sibling relationship may be an important factor in mediating or moderating those outcomes.

From the perspective of family psychology, experiencing positive relationships with meaningful people, which includes sisters and brothers, is relevant for forming a positive sense of self and value. When parents are unavailable, uncaring, or neglectful, siblings may become important figures in one's development (Bowlby 1988; Byng-Hall 2008). In most cultures, sibling relationships are one of the longest-lasting because they start at the time of the birth of the younger sibling. In the case of twins, the relationship has already begun during the fetal period (Capodieci 2006; Namysłowska and Siewierska 2009; Rostowska 2010). In most families, the sibling subsystem is two or more children with at least one common parent (Harwas-Napierała 2008; Noller 2005; Noller et al. 2008; Rostowska 2010). The functioning of the sibling subsystem is based on mutual interactions, feelings toward one another, and attitudes toward common or individual experiences. Irrespective of the stage of life, sisters and brothers may provide companionship, caring for and helping each other (Goetting 1986; Lempers and Clark-Lempers 1992). In adult life, they cooperate in caring for elderly parents, often trusting each other in the matters of their own 
families, and share memories and experiences from their family of origin (Lewandowska-Walter et al. 2016). Siblings can also be important role models for each other. Therefore, sisters and brothers influence each other and have a mutual contribution to one's individual development (Buhrmester 1992; Furman and Buhrmester 1985).

The fact that sibling relationships typically last from the cradle to the grave does not mean they are unalterable or always positive. On the contrary, throughout life, sibling relationships are constantly evolving. Their intensity and degree of intimacy are changing, alongside with the ways in which siblings communicate and resolve conflict (Namysłowska and Siewierska 2009). Barbaro de (1999) described the sibling relationship as a social laboratory in which children experience their first peer interaction. Later social experiences may be modeled after the quality of relationships with sisters and brothers (Namysłowska 2001). Importantly, even though a parentified child may be limited in the interactions with their peers outside of the family system, the sibling relationship may afford the parentified child a similar developmental experience. Additionally, the specificity of the sibling relationship allows for the emergence of a range of interpersonal processes, which are likely different than the relationships evidenced with parents, which tend to be more hierarchical than sibling relationships (Lewandowska-Walter et al. 2016).

Indeed, sibling relationships can be a significant predictor of adolescent functioning as well as a pathway between childhood parentification and select outcomes, including the adaptation to the family life as well as to the society in general (Lewandowska-Walter et al. 2016). As a result of positive interactions with sisters and brothers, adolescents experience warmth, encouragement, acceptance, and support. Those interactions may increase the chance to discover one's own value, adequacy, and confidence, which in turn can contribute to high self-esteem (Amato 1990; Harter 1999; Yeh and Lempers 2004).

Social and family psychology theories provide a framework to inform the examination of the link between parentification and self-esteem. According to Rosenberg's (1965) classic theory, people have different attitudes toward various objects and subjects, and their own self is also one of them. Self-esteem describes someone's perception of $m e$ (Rosenberg 1965). Self-esteem may also be viewed as a concept of a hierarchical structure (Wojciszke 2002). Specifically, the lower levels of self-esteem include the elements of self-image located within specific areas (e.g., one's opinion on their own intelligence, personality traits, abilities, or physical attractiveness). Those unique aspects of self-esteem are also related to specific domains-and combined-represent one's overall or global self-esteem (Oleszkowicz and Senejko 2011; Wojciszke 2002). Wojciszke (2002) distinguishes the emotional component of one's self-esteem and describes it as "an affective reaction to oneself" (p. 147). Conceptualized as an affective reaction, one's self-esteem may take the form of either a cold judgment based on rationality or a hot intense emotion. Therefore, self-esteem may be investigated in the context of one's permanent trait (e.g., judgment or attitude toward oneself) or as an ongoing motive or state that is being experienced by an individual (Wojciszke 2002). Rosenberg's (1965) view of self-esteem is closer to the concept of one's permanent characteristic.

Guided by the tenets of family systems theory, defense mechanisms, and posttraumatic growth, Borchet et al. (2016) found a positive relation between parentification and self-esteem. The authors contended that taken together, the act of childhood family caregiving and the participants' positive view of their caregiving roles and experiences (i.e., perceived benefits of parentification) facilitated selfreported beneficial outcomes of parentification. Selfesteem has emerged as a commonly investigated positive outcome of parentification as feelings of competence and self-efficacy, which could have been gained while performing family caregiving, are elements of one's positive self-image (Wojciszke 2002). This finding is in alignment with the literature suggesting that self-esteem may be one of the positive outcomes of experiencing adaptive/constructive parentification (e.g., Burton 2007; Chase 1999) or a longterm effect of adaptive coping skills gained while performing adult-like roles in the family (Stein et al. 2007). Walker and Lee (1998) examined the connections among parentification, self-esteem, and perceived advantages of engaging in role reversal in the family system where alcoholism existed. They found sibling relationships fostered resilience among the study participants. More specifically, "children of alcoholics" indicated sibling relationships were a relational resource. Walker and Lee (1998) asserted that "sibling studies are needed to find out if parentification with brothers and sisters leads to conventional belief systems, non-problematic use of substances, and ego strength" (pp. 532-533). Importantly, studies exploring the importance of sibling relationships on current and later relationships and outcomes have often produced interesting findings including a positive association between destructive parentification and low self-esteem (Wells et al. 1999), although more research is needed among international samples specifically.

\section{The Current Study}

The deleterious effects of parentification are well documented (Boszormenyi-Nagy and Spark 1973; Hooper et al. 2014). Thus, studies that explore factors that may disrupt the commonly seen negative outcomes are important. One factor that may buffer the relation between parentification 
and negative family structures, events, and experiences is the relationship an individual has with her or his siblings (Burton et al. 2018; Fitzgerald et al. 2008; Milevsky and Levitt 2005). Relationships with siblings and caring for them may have a significant impact on the development of an individual. On the other hand, an individual compelled to engage in caregiving responsibilities may feel that the load assigned to them is inequitable and thus exacerbates conflicts among siblings based on the parents' differential treatment. As a consequence, an individual may experience difficulties in social adaptation (McHale et al. 2000). However, most adults who have experienced family difficulties and challenges in childhood view the relationship with their sisters and brothers in a positive manner (Jenkins 1992; Tomeny et al. 2016). Thus, this positive relationship may have a significant buffering effect on the connection between parentification and select outcomes such as selfesteem. Informed by the literature, the current study examined two research questions: (a) to what extent are perceived benefits of parentification positively associated with self-esteem (b) to what extent does the quality of sibling relationships mediate the relation between perceived benefits of parentification and self-esteem?

\section{Method}

\section{Participants}

Participants in the current study were 218 late adolescents from Poland $(M=21.37 ; S D=2.49 ; \quad M d n=21)$. The majority were female $(86.2 \% ; n=188)$. Most participants self-identified as university students $(84.9 \% ; n=185)$ living outside the family home $(62.4 \% ; n=136)$. The remaining participants had secondary education $(4.1 \%$; $n=$ $9)$ or higher $(11 \% ; n=24)$. Approximately half of the group were in a casual relationship $(52 \% ; n=113), 43.6 \%(n=$ 96) were single, and $4.1 \%(n=9)$ were married. More than half of the participants were unemployed $(55 \% ; n=120)$. However, some of them had full-time $(16.5 \% ; n=36)$ or part-time jobs $(28.4 \% ; n=62)$. Their families of origin were full (i.e., non-divorced nuclear families; $85.8 \% ; n=$ 187). The number of the siblings ranged from 1 to $6(n=1$, $64.2 \% ; n=2,22 \% ; n=3,8.7 \% ; n=4,3.2 \% ; n=5,1.4 \%$; $n=6,0.5 \%$ ).

\section{Procedure}

Informed consent was obtained from all participants before they started the questionnaire. The study used an online version of the questionnaire using the Lime Survey platform. The link to the questionnaire was distributed to social networking websites of universities across the
Poland region. Participants voluntarily completed the survey.

\section{Measures}

Three questionnaires were used in the study: Polish adaptation of Hooper's Parentification Inventory (Hooper 2009), The Questionnaire of Relationships with Siblings (Lewandowska-Walter et al. 2016), and the Polish adaptation of Rosenberg's Self-esteem Scale (SES; Łaguna et al. 2007).

\section{Parentification}

The perceived benefits of parentification dimension were the predictor variable and it was assessed using the Parentification Inventory (PI; Hooper 2009). The PI was designed to retrospectively assess the extent to which the person performed caregiving roles toward family members while being a child, and to assess to what extent the experience of parentification is perceived to have been beneficial. The 22-item PI has three subscales: parentfocused parentification (12 items, e.g., "I often help solve problems between my parent(s)"), sibling-focused parentification (7 items, e.g., "I am the primary person who disciplines my siblings"), and perceived benefits of parentification ( 3 items, e.g., "I feel like our family is a team and works well together"). Participants self-reported the extent to which they experienced each statement on a Likert-type 5 -point scale $(1=$ never true and $5=$ always true), with higher scores indicating higher perceived levels of parentification or benefits of parentification.

The study used a Polish adaptation of the PI. The forward and backward translation process for the resulting PI was conducted as recommended by Sireci and Berberoglu (2000). Additionally, the backward translation was examined by a person with a degree in English. Factor analyses of the translated version of the PI showed a good model fit for the 12 item solution (Borchet et al. under review). Additionally, the resultant three factors, produced sound reliability (i.e., from 0.77 to 0.81 ). The study used the perceived benefits of parentification subscale score only. Its reliability in the current study was sound (i.e., Cronbach's $\alpha$ : 0.77).

\section{Relationships with Siblings}

Sibling relationships served as a mediator variable. It was a latent variable composed of 3 measurable variables describing characteristics of sibling relationships-cohesion, communication, and rivalry. These dimensions were assessed using the Questionnaire of Relationships with Siblings (Lewandowska-Walter et al. 2016). The Questionnaire of Relationships with Siblings was designed to 
Table 1 Summary statistics and correlations between study variables $(N=218)$

\begin{tabular}{lrlllllllll}
\hline Variable & $M$ & $S D$ & Min & Max & $\alpha$ & 1 & 2 & 3 & 4 \\
\hline $\begin{array}{l}\text { 1. Perceived benefits of } \\
\text { parentification }\end{array}$ & 3.22 & 0.98 & 1.00 & 5.00 & 0.77 & & & & \\
2. Self-esteem & 28.07 & 6.28 & 10.00 & 41.00 & 0.90 & $0.40^{* *}$ & & & \\
3. Cohesion & 3.33 & 0.63 & 1.50 & 4.63 & 0.86 & $0.54^{* *}$ & $0.36^{* *}$ & & \\
4. Communication & 3.17 & 0.77 & 1.17 & 4.67 & 0.85 & $0.47^{* *}$ & $0.32^{* *}$ & $0.85^{* *}$ & \\
5. Rivalry & 2.02 & 0.70 & 1.00 & 4.17 & 0.79 & $-0.30^{* *}$ & $-0.23^{* *}$ & $-0.35^{* *}$ & $-0.34^{* *}$ \\
\hline
\end{tabular}

Perceived benefits of parentification-Parentification Inventory (Hooper, 2009); Self-esteem-Rosenberg's Self-esteem Scale (Łaguna et al. 2007); Cohesion, Communication \& Rivalry-Questionnaire of Relationships with Siblings (Lewandowska-Walter et al., 2016)

$* * p<0.01$

assess the relationship quality among Polish siblings (Lewandowska-Walter et al. 2016). The 20-item questionnaire is composed of three subscales: cohesion $(8$ items, e.g., "I have a feeling that my siblings are very close to me"), communication (6 items, e.g., "Even when I disagree, I listen to my siblings' arguments"), and rivalry (6 items, e.g., "My siblings are trying to be better than me"). Cohesion determines the strength of bonding between siblings on a continuum from a strong bond to the absence of a bond. Communication is a dimension extending from normal to problematic communication between siblings. The third subscale, Rivalry, ranges from a positive competitive stance to envy. Participants rated how often they experience these behaviors and feelings about their sibling on a Likert-type 5-point scale $(1=$ never and $5=$ very often). The scores of each subscale are calculated by summing the items for each subscale. Total scores for scores for the cohesion dimension ranged from 8 to 40, whereas for the communication and rivalry dimensions ranged from 6 to 30. Reliability in the current study was sound: cohesion (Cronbach's $\alpha$ : 0.86), communication (Cronbach's $\alpha: 0.85$ ), and rivalry (Cronbach's $\alpha: 0.79)$.

\section{Self-esteem}

Self-esteem was the outcome variable for the study and was measured by the Rosenberg's Self-esteem Scale (Rosenberg 1965). Rosenberg's Self-esteem Scale was designed to measure overall levels of self-esteem. Participants responded using a four-point Likert-type scale ( $1=$ strongly agree to $4=$ strongly disagree). The Rosenberg's Self-esteem Scale (Rosenberg 1965) and the adapted scale (Łaguna et al. 2007) are comprised of 10 items. Total scores range from 10 to 40 points. Previous studies report sound reliability (Cronbach's $\alpha$ : 0.81-0.83) and theoretically valid scores derived from the adapted Polish version of the scale (Eaguna et al. 2007). Reliability in the current study was sound (Cronbach's $\alpha$ : 0.90).

\section{Analytic Strategy}

Descriptive statistics of the group, Pearson correlations between variables, and the reliability of the measures (see Table 1) were assessed with Statistical Package for Social Science (SPSS) 24.

After initial analyses, structural equation modeling was performed using AMOS 24 software. Model fit was judged using the comparative fit index (CFI), goodness-of-fit index (GFI), and root mean square error of approximation (RMSEA). With respect to the fit indices, GFI and CFI values greater than 0.90 were considered as well-fitted (Konarski 2010). RMSEA values lower than or equal to 0.08 or 0.06 indicate acceptable or good fit (Hu and Bentler 1999). Partial mediation was recognized consistent with Baron and Kenny's (1986) criteria. In order to test to what extent perceived benefits of parentification are positively associated with self-esteem among a sample of Polish late adolescents, and to what extent does the quality of the sibling relationship mediate the association between perceived benefits of parentification and self-esteem, we examined the direct and indirect effects using SEM models (AMOS 24). The model tested was well-suited to the data and interpretable (Konarski 2010).

\section{Results}

We found that the perceived benefits of parentification ( $\mathrm{B}=0.56, p=0.001)$ were highly related to the quality of sibling relationships (Fig. 1). In addition, the quality of sibling relationships was also positively $(\mathrm{B}=0.22, p=$ 0.001) associated with the level of self-esteem. Because both the A-path and B-path were statistically significant, the mediation analyses were tested using the bootstrapping method with bias-corrected confidence estimates (Preacher and Hayes 2008). In this study, the $95 \%$ confidence interval (CI) of the indirect effects was obtained with 1000 bootstrap resamples. The results of the analyses of direct and indirect effects for the assumed model indicated partial mediation in 


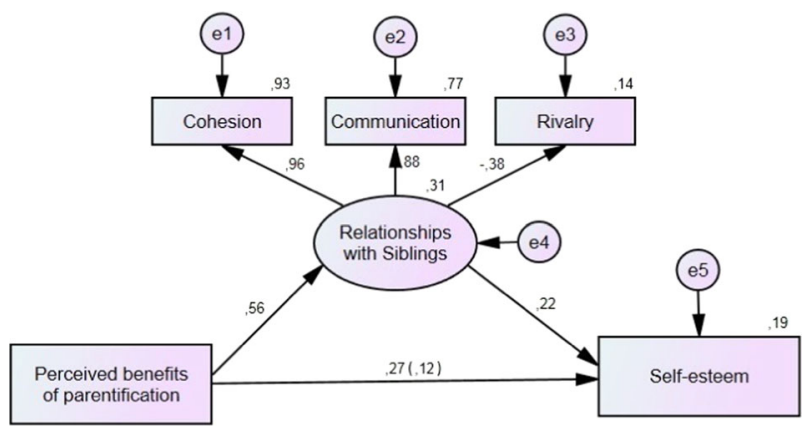

Fig. 1 The mediating effect of the sibling relationships on the relation between perceived benefits of parentification and self-esteem

relation to the perceived benefits of parentification and selfesteem. The perceived benefits of parentification and selfesteem in the context of sibling relationships remained positive $(\mathrm{B}=0.124 ; p<0.01)$. In summary, the assumed model was confirmed due to statistically significant partial mediation effect (direct effect: $0.272 ; p<0.001$; indirect effect: 0.124; $p<0.01$; see: Baron and Kenny 1986). The model parameters were satisfying $(\mathrm{CMIN}=52.735$ (42); $p=0.124 ; \mathrm{RMSEA}=0.012 ; \mathrm{GFI}=0.990 ; \mathrm{CFI}=0.996$ )

\section{Discussion}

The aim of the study was to explore to what extent perceived benefits of parentification are positively associated with self-esteem, and to what extent the quality of sibling relationships mediates the relation between perceived benefits of parentification and self-esteem. The study yielded two important findings: (a) a positive view or perception of the benefits of family caregiving (parentification) was related to higher levels of self-esteem and (b) the quality of sibling relationships partially mediated the link between perceiving the advantages of parentification and selfesteem.

The first finding could stem from the fact that participants may have experienced constructive parentification (e.g., Chase 1999; Jurkovic 1997). For example, irrespective of being burdened with caregiving responsibilities in their families, it is plausible that they also received gratitude from their family members and this recognition boosted their confidence and positive view of self. The literature suggests children and adolescents performing certain caregiving functions and roles in the family system, and who also perform typical "adult-like" duties may feel appreciated, important, needed, and have a sense of well-being (e.g., Hooper et al. 2014). These roles and responsibilities might underpin or engender self-efficacy and feelings of competence, which in fact are positive components of one's self-image (e.g., Wojciszke 2002). Having high levels of self-esteem, while also being parentified, may serve as a defense mechanism, which sustains or increases a high level of positivity and beliefs about oneself (Borchet et al. 2016). In this context, a person builds her or his self-enhancement with favorable judgments about oneself and through various complex psychological mechanisms such as self-affirmation, performing social comparisons, cognitive dissonance reduction, auto-presentation, or biased processing of information about oneself (Wojciszke 2002). Self-enhancement, one of the most interesting strategies of self-affirmation, can be done in many ways. For example, engaging in moral action, success, or expressing the values with which the individual identifies (Wojciszke 2002). In positive psychology, Park et al. (2004) describe how the process of engaging in complicated tasks related to the need to adapt to life can be a trigger for shaping a strong character. With respect to the experience of parentification during childhood, positive reframing of the difficulties can be a conscious action aimed at protecting and strengthening one's self-image, and can be an element of self-regulation (selfcontrol) as one of the strengths of character (Park et al. 2004). This reframing or creating an alternate view allows for a meaningful life by those who have suffered in the past (Seligman and Csikszentmihalyi 2000).

In the families where the parent is not able to perform her or his parental roles and tasks, an unintended opportunity may emerge. Specifically, serving in the parentified role in the family of origin may enable a child to build their selfesteem through the identification with the role assigned and by performing parental roles and responsibilities, ultimately engendering feelings of self-enhancement, self-approval, or competence (e.g., Borchet et al. 2016; Schier 2014). Additionally, one's perception of family relationships-and indirectly outcomes-are connected with the level of control over one's own actions, self-efficacy, and beliefs about the ability to cope with severe situations and crises (e.g., Plopa and Połomski 2010). Thus, to maintain an attachment with the parent, the child adapts to the parent's needs and creates a system of care for them while deserting one's own true self (Schier 2010, 2014; Wells et al. 1999). As a result, children, who excessively take care of their parents, and other family members may build psychic structures that are unfavorable for their own identity yet adjusted to their deleterious environment, and thus their so-called false self. The false image of oneself is being presented to others (Winnicott 1958). Consistent with these theoretical assumptions, the link between high self-esteem and perceived benefits of parentification may be framed as a defense mechanism.

Results in the current study may have been impacted by counseling and psychotherapy. Specifically, it remains unclear to what extent participants had a history of treatment that addressed or lessened the later effects or possible negative effects of parentification. Thus, the period from 
when childhood parentification took place to current functioning could have allowed for an adequate amount of time to reduce the negative outcomes and underscore the positive outcomes of parentification, which directly enhances the self-esteem of an adult person. This conclusion is inconsistent with the tenets of posttraumatic growth, which outline how an individual may experience development or psychological growth by overcoming adverse and traumatic experiences (Hooper et al. 2009; Taku and McDiarmid 2015; Tedeschi and Calhoun 1996). Findings from Taku and McDiarmid's (2015) study showed that self-esteem was connected to posttraumatic growth. Another study involving adolescents showed that self-esteem may buffer the negative aftereffects of stressful experiences (Moksnes et al. 2010).

The second hypothesis may have been supported due to the relationship between siblings. There is a plethora of research on social support (e.g., Sęk and Cieślak 2004) but the studies on the mutual support between siblings are still scarce. Experiencing parentification in the family may pose a threat to the child's development (e.g., Chase et al. 1998; Hooper et al. 2008, 2011; Schier 2010, 2014). However, in such situations, children are not always passive, rather in some families, they are capable and active participants in what is happening around them and in the family system. Their actions also may build up or have significant levels of competence or resilience. Their relationships with siblings and their related caregiving functions may, for instance, become the resource that helps them to cope with violence in the family home (Callaghan et al. 2016). In Callaghan et al.'s (2016) study, caring for siblings was one form of a caring relationship in which the children were engaged. The children who experienced domestic violence tended to manage their relationships with others in ways that enabled them to be agentic, as well as to create a resistant and resilient sense of self (Callaghan et al. 2016). Those findings seem to be consistent with the current study. The more positive the late adolescents' relationships with their siblings were, the higher their self-esteem and the more perceived benefits of parentification were reported. Perhaps their alliance with siblings and mutual support received during their childhood shaped their feeling of self-agency, and resilience boosting their self-esteem. This hypothesis was supported by Walker and Lee's study on children of alcoholics_COAs (1998). Walker and Lee (1998) revealed that supportive relationships with non-substance using parents and/or siblings, as well as positive parentification, may enable a significant proportion of COAs to experience high self-esteem, lack of excessive substance use, and adaptability. Furthermore, research conducted in the Taiwanese population revealed that the higher the level of parentification that children and adolescents reported, the more pro-social behaviors they performed (Chi-Yin and
Lee-Fang 2013). Moreover, taking care of siblings was found to be the most effective predictor of pro-social behavior (Chi-Yin and Lee-Fang 2013). This finding seems to be consistent with the fact that late adolescents who sustain good relationships with their siblings have high selfesteem and perceive their experience of parentification as beneficial.

\section{Limitations and Future Directions}

Limitations of the study include a small sample size and an underrepresentation of male participants. Additionally, participants consisted of volunteers and thus it is unclear to what extent they had a particular interest in the topic and thus were motivated to participate. An additional limitation was that the survey was conducted using Lime Survey, an internet platform. However, the online survey methodology employed facilitated the recruitment of late adolescents from various cities in Poland. Finally, there were other variables that were not measured that may better explain pathways related to parentification, sibling relationships, and self-esteem. For example, other important variables that may have relevance to the structure of the sibling subsystem include, but are not limited to, the number of children in the family, age, birth order, the span of each child's age (Rostowska 2010), and personality. Such variables are recommended to be included in future research.

The current study demonstrated that the relations between self-esteem and perceived benefits of parentification may be considered through the prism of sibling relationships. The obtained results showed that it is important to consider the quality of the sibling relationship while assessing the perceived benefits of family roles, responsibilities, dysfunction, and difficulties (e.g., Tomeny et al. 2016). Importantly, in the context of client care and practice, the quality and strength of sibling subsystems are often still underexplored during psychological assessment and diagnostic interviews (e.g., Birch 2005; Walker and Lee 1998). As the current study shows, sibling relationships may serve as a buffer protecting children from the negative outcomes of parentification, enabling them to develop resilience, feelings of self-agency, and high levels of selfesteem. Further research on parentification and sibling relationships is recommended. Additionally, future research might consider other factors in the sibling relationship, such as personality, that could relate to positive outcomes from parentification.

Acknowledgements Grant Number: 538-7400-B185-18, Grant for young scientists and participants of doctoral studies at University of Gdańsk' Faculty of Social Sciences for 2018.

Author Contributions J.B.: designed and executed the study, wrote, and edited the paper. A.L.W.: collaborated with the study design and 
writing of the paper. P.P.: analyzed the data and wrote part of the results. A.P.: collaborated in the writing. L.M.H.: collaborated in the writing and editing of the paper.

\section{Compliance with Ethical Standards}

Conflict of Interest The authors declare that they have no conflict of interest.

Ethical Approval All procedures performed in studies involving human participants were in accordance with the ethical standards of the institutional and/or national research committee and with the 1964 Helsinki declaration and its later amendments or comparable ethical standards. This study received the approval of the Institutional Review Board from the Institute of Psychology, University of Gdańsk.

Informed Consent Informed consent was obtained from all individual participants included in the study.

Publisher's note Springer Nature remains neutral with regard to jurisdictional claims in published maps and institutional affiliations.

Open Access This article is licensed under a Creative Commons Attribution 4.0 International License, which permits use, sharing, adaptation, distribution and reproduction in any medium or format, as long as you give appropriate credit to the original author(s) and the source, provide a link to the Creative Commons license, and indicate if changes were made. The images or other third party material in this article are included in the article's Creative Commons license, unless indicated otherwise in a credit line to the material. If material is not included in the article's Creative Commons license and your intended use is not permitted by statutory regulation or exceeds the permitted use, you will need to obtain permission directly from the copyright holder. To view a copy of this license, visit http://creativecommons. org/licenses/by/4.0/.

\section{References}

Aldridge, J., \& Becker, S. (1993). Punishing children for caring: the hidden cost of young carers. Children \& Society, 7(4), 376-387. https://doi.org/10.1111/j.1099-0860.1993.tb00293.x.

Amato, P. R. (1990). Dimensions of the family environment as perceived by children: a multidimensional scaling analysis. Journal of Marriage and the Family, 52(3), 613-620. https://doi.org/10. $2307 / 352928$.

Barbaro de, B. (1999). Wprowadzenie do systemowego rozumienia rodziny [Introduction to family systems theory]. Kraków: Wydawnictwo Uniwersytetu Jagiellońskiego.

Baron, R. M., \& Kenny, D. A. (1986). The moderator-mediator variable distinction in social psychological research: conceptual, strategic and statistical considerations. Journal of Personality and Social Psychology, 51(6), 1173-1182. https://doi.org/10.1037/ 0022-3514.51.6.1173.

Birch, A. (2005). Psychologia rozwojowa $w$ zarysie [Developmental psychology]. Warszawa: Wydawnictwo Naukowe PWN.

Borchet, J., Hooper, L.M., Lewandowska-Walter, A., Peplińska, A., Połomski, P., \& Rostowska, T. (under review). Assessing Retrospective Parentification in Polish Emerging Adults: An Investigation of a Polish Version of the Parentification Inventory.

Borchet, J., Lewandowska-Walter, A., \& Rostowska, T. (2016). The relationship between the experience of parentification and self- esteem among young adults. Polish Journal of Social Science, 11 (1), 99-113.

Boszormenyi-Nagy, I., \& Spark, G. (1973). Invisible loyalties: reciprocity in intergenerational family therapy. New York, NY: Harper and Row.

Bowlby, J. (1988). A secure base: parent-child attachment and healthy human development. New York, NY: Basic Books.

Buhrmester, D. (1992). The developmental courses of sibling and peer relationships. In F. Boer \& J. Dunn (Eds.), Children's sibling relationships: developmental and clinical issues (pp. 19-40). Hillsdale, NJ: Lawrence Erlbaum Associates.

Burton, L. (2007). Childhood adultification in economically disadvantaged families: A conceptual model. Family Relations, 56 (4), 329-345. https://doi.org/10.1111/j.1741-3729.2007.00463.x.

Burton, S., Hooper, L. M., Tomek, S., Cauley, B., Washington, A., \& Pössel, P. (2018). The mediating effects of parentification on the relation between parenting behavior and depression and wellbeing in early adolescents. Journal of Child and Family Studies, 27, 4044-4059. https://doi.org/10.1007/s10826-018-1215-0.

Byng-Hall, J. (2008). The significance of children fulfilling parental roles: implications for family therapy. Journal of Family Therapy, 30(2), 147-162. https://doi.org/10.1111/j.1467-6427.2008. 00423.x.

Callaghan, J., Alexander, J. H., Sixsmith, J., \& Fellin, L. C. (2016). Children's experiences of domestic violence and abuse: Siblings' accounts of relational coping. Clinical Child Psychology and Psychiatry, 21(4), 649-668. https://doi.org/10.1177/ 1359104515620250.

Capodieci, S. (2006). Rodzeństwo - Jaś i Matgosia czy Kain i Abel [Siblings-Hansel and Gretel or Cain and Abel]. Warszawa: Pax.

Carroll, J. J., \& Robinson, B. E. (2000). Depression and parentification among adults as related to parental workaholism and alcoholism. The Family Journal, 8(4), 360-367. https://doi.org/10.1177/ 1066480700084005.

Chase, N. (1999). An overview of theory, research, and societal issues. In N. Chase (Ed.), Burdened children (pp. 3-33). New York, NY: Guilford.

Chase, N. D., Deming, M. P., \& Wells, M. C. (1998). Parentification, parental alcoholism, and academic status among young adults. American Journal of Family Therapy, 26(2), 105-114. https:// doi.org/10.1080/01926189808251091.

Chi-Yin, H., \& Lee-Fang, T. (2013). What are positive implications of parentification? The relationship between parentification and prosocial behavior of children and adolescents in the underprivileged family. The Archive of Guidance \& Counseling, 35(2), $25-46$.

Fitzgerald, M. M., Schneider, R. A., Salstrom, S., Zinzow, H. M., Jackson, J., \& Fossel, R. V. (2008). Child sexual abuse, early family risk, and childhood parentification: pathways to current psychosocial adjustment. Journal of Family Psychology, 22(2), 320-324. https://doi.org/10.1037/0893-3200.22.2.320.

Furman, W., \& Buhrmester, D. (1985). Children's perceptions of the qualities of their sibling relationships. Child Development, 56(2), 448-461. https://doi.org/10.2307/1129733.

Goetting, A. (1986). The developmental tasks of siblingship over the life cycle. Journal of Marriage and the Family, 48(4), 703-714. https://doi.org/10.2307/352563.

Harter, S. (1999). Symbolic interactionism revisited: potential liabilities for the self-constructed in the crucible of interpersonal relationships. Merrill-Palmer Quarterly, 45(4), 677-703.

Harwas-Napierała, B. (2008). Komunikacja interpersonalna $w$ rodzinie [Interpersonal communication in the family]. Poznań: Wydawnictwo Naukowe UAM.

Haxhe, S. (2016). Parentification and related processes: distinction and implications for clinical practice. Journal of Family 
Psychotherapy, 27(3), 185-199. https://doi.org/10.1080/ 08975353.2016.1199768.

Hooper, L.M. (2009). Parentification inventory. (Available form L. M. Hooper, 108 Schindler Education Center, 50614-0410), Cedar Falls, IA: University of Northern Iowa.

Hooper, L. M. (2014). Assessing parentification in South American college students: a factor analytic study of a Spanish version of the Parentification Inventory. Journal of Multicultural Counseling and Human Development, 42(2), 93-106. https://doi.org/10. 1002/j.2161-1912.2014.00047.x.

Hooper, L. M., DeCoster, J., White, N., \& Voltz, M. L. (2011). Characterizing the magnitude of the relation between selfreported childhood parentification and adult psychopathology: a meta-analysis. Journal of Clinical Psychology, 67(10), 1028-1043. https://doi.org/10.1002/jclp.20807.

Hooper, L. M., Doehler, K., Jankowski, P. J., \& Tomek, S. E. (2012). Patterns of self-reported alcohol use, depressive symptoms, and body mass index in a family sample: the buffering effects of parentification. The Family Journal, 20(2), 164-178. https://doi. org/10.1177/1066480711435320.

Hooper, L.M., L'Abate, L., Sweeney, L., Gianesini, G., \& Jankowski, P. (2014). Models of psychopathology: Generational processes and relational roles. In: Parentification (pp. 37-54). New York, NY: Springer. https://doi.org/10.1007/978-1-4614-8081-5.

Hooper, L. M., Marotta, S. A., \& Depuy, V. (2009). A confirmatory factor analytic study of the Posttraumatic Growth Inventory among a sample of racially diverse college students. Journal of Mental Health, 18(4), 335-343.

Hooper, L. M., Marotta, S. A., \& Lanthier, R. P. (2008). Predictors of growth and distress following childhood parentification: a retrospective exploratory study. Journal of Child \& Family Studies, 17 (5), 693-705. https://doi.org/10.1007/s10826-007-9184-8.

Hooper, L. M., \& Wallace, S. A. (2010). Evaluating the Parentification Questionnaire: psychometric properties and psychopathology correlates. Contemporary Family Therapy, 32(1), 52-68. https:// doi.org/10.1007/s10591-009-9103-9.

Hu, L., \& Bentler, P. M. (1999). Cutoff criteria for fit indexes in covariance structure analysis: conventional criteria versus new alternatives. Structural Equation Modeling, 6(1), 1-55. https:// doi.org/10.1080/10705519909540118.

Jenkins, J. M. (1992). Sibling relationships in disharmonious homes: Potential difficulties and protective effects. In F. Boer \& J. Dunn (Eds.), Children's sibling relationships: Developmental and clinical issues (pp. 125-138). Hillsdale, NJ: Erlbaum.

Jurkovic, G. J. (1997). The plight of the parentified child. New York, NY: Brunner Mazel.

Konarski, R. (2010). Modele równań strukturalnych. Teoria i praktyka [Structural equation modelling. Theory and practice]. Warszawa: Wydawnictwo Naukowe PWN.

Łaguna, M., Lachowicz-Tabaczek, K., \& Dzwonkowska, I. (2007). Skala samooceny SES Morrisa Rosenberga - polska adaptacja metody [SES Morris Rosenberg self-assessment scale-Polish adaptation of the method]. Psychologia Spoteczn, 24(4), $164-176$.

Lempers, J. D., \& Clark-Lempers, D. S. (1992). Young, middle, and late adolescents' comparison of the functional importance of five significant relationships. Journal of Youth and Adolescence, 21 (1), 53-96. https://doi.org/10.1007/BF01536983.

Lewandowska-Walter, A., Połomski, P., \& Peplińska, A. (2016). Kwestionariusz Relacji z Rodzeństwem w okresie adolescencji [Questionnaire of Relationships with Siblings for adolescents]. Gdańsk: Pracownia Testów Psychologicznych i Pedagogicznych.

McHale, S. M., Updegraff, K. A., Jackson-Newsom, J., Tucker, C. J., \& Crouter, A. C. (2000). When does parents' differential treatment have negative implications for siblings? Social Development, 9(2), 149-172. https://doi.org/10.1111/1467-9507.00117.
Mika, P., Bergner, R. M., \& Baum, M. C. (1987). The development of a scale for the assessment of parentification. Family Therapy, 14 (3), 229-235.

Milevsky, A., \& Levitt, M. J. (2005). Sibling support in early adolescence: buffering and compensation across relationships. European Journal of Developmental Psychology, 2(3), 299-320. https://doi.org/10.1080/17405620544000048.

Minuchin, S. (1974). Families and family therapy. Cambridge, MA: Harvard University Press.

Moksnes, U. K., Moljord, I. E., Espnes, G. A., \& Byrne, D. G. (2010). The association between stress and emotional states in adolescents: the role of gender and self-esteem. Personality and Individual Differences, 49(5), 430-435. https://doi.org/10.1016/j.pa id.2010.04.012.

Namysłowska, I. (2001). Terapia rodzin [Family therapy]. Warszawa: Instytut Psychiatrii i Neurologii.

Namysłowska, I., \& Siewierska, A. (2009). Znaczenie i rola rodzeństwa $w$ terapii rodzin [The role and significance of siblings in family therapy]. Psychoterapia, 2(149), 45-56.

Noller, P. (2005). Sibling relationships in adolescence: learning and growing together. Personal Relationship, 12(1), 1-22. https://doi. org/10.1111/j.1350-4126.2005.00099.x.

Noller, P., Feeney, J. A., Sheehan, G., Darlington, Y., \& Rogers, C. (2008). Conflict in divorcing and continuously married families: a study of marital, parent-child and sibling relationships. Journal of Divorce and Remarriage, 49(1-2), 1-24. https://doi.org/10.1080/ 10502550801971223.

Oleszkowicz, A., \& Senejko, A. (2011). Dorastanie [Growing up]. In J. Trempała (ed.), Psychologia rozwoju człowieka [Psychology of human development] (pp. 259-286). Warszawa: Wydawnictwo Naukowe PWN.

Park, N., Peterson, C., \& Seligman, M. E. (2004). Strengths of character and well-being. Journal of Social and Clinical Psychology, 23(5), 603-619. https://doi.org/10.1521/jscp.23.5.603.50748.

Peris, T. S., Goeke-Morey, M. C., Cummings, E. M., \& Emery, R. E. (2008). Marital conflict and support seeking by parents in adolescence: empirical support for the parentification construct. Journal of Family Psychology, 22(4), 633-642. https://doi.org/ 10.1037/a0012792.

Plopa, M., \& Połomski, P. (2010). Kwestionariusz Relacji Rodzinnych. Wersja dla młodzieży [Questionnaire for family relationships. Version for adolescents]. Warszawa: Wydawnictwo VIZJA PRESS \& IT.

Preacher, K. J., \& Hayes, A. F. (2008). Asymptotic and resampling strategies for assessing and comparing indirect effects in multiple mediator models. Behavior Research Methods, 40(3), 879-891. https://doi.org/10.3758/BRM.40.3.879.

Rosenberg, M. (1965). Society and adolescent self-image. New York, NY: Princeton University Press.

Rostowska, T. (2010). Psychospołeczne aspekty relacji interpersonalnych $\mathrm{w}$ podsystemie rodzeństwa bliźniąt monozygotycznych [Psychosocial aspects of interpersonal relationships within the siblings subsystem in monozygotic twins]. In Rostowska, W.T. \& Pastwa-Wojciechowska, B. (eds.). Rozwój bliźniat $w$ ciagu zycia. Aspekty biopsychologiczne [Twins development during lifetime. Biopsychological aspects]. (pp. 101-122). Kraków: Impuls.

Schier, K. (2010). Gdy dziecko staje się rodzicem—odwrócona troska, czyli zjawisko parentyfikacji w rodzinie [When a child becomes a parent-reversed care, that is parentificaion phenomena in the family]. In B. Tryjarska (ed.), Bliskość $w$ rodzinie. Więzi $w$ dziecinstwie a zaburzenia $w$ dorostości [Closeness in the family. Bonds in the childhood and disorders in adulthood] (pp. 63-80). Warszawa: Wydawnictwo Naukowe Scholar.

Schier, K. (2014). Doroste dzieci. Psychologiczna problematyka odwrócenia ról $w$ rodzinie [Adult children. Psychological aspects 
of reversing roles in the family]. Warszawa: Wydawnictwo Naukowe SCHOLAR.

Sęk, H., \& Cieślak, R. (2004). Wsparcie spoteczne, stres $i$ zdrowie [Social suport, stress and health]. Warszawa: Wydawnictwo Naukowe PWN.

Seligman, M. E. P., \& Csikszentmihalyi, M. (2000). Positive psychology. An introduction. American Psychologist, 55(1), 5-14. https://doi.org/10.1037/0003-066X.55.1.5.

Shih, F. M., Wu, L. C., \& Lin, S. H. (2010). A correlational study on parentification, self-differentiation, and health for students in senior high and vocational high school in Taiwan. Bulletin of Educational Psychology, 41(4), 823-846.

Sireci, S. G., \& Berberoglu, G. (2000). Using bilingual respondents to evaluate translated-adapted items. Applied Measurement in Education, 13(3), 229-248. https://doi.org/10.1207/S15324818AME1303_1.

Stein, J. A., Rotheram-Borus, M. J., \& Lester, P. (2007). Impact of parentification on long-term outcomes among children of parents with HIV/AIDS. Family Process, 46(3), 317-333. https://doi.org/ 10.1111/j.1545-5300.2007.00214.x.

Taku, K., \& McDiarmid, L. (2015). Personally important posttraumatic growth in adolescents: the effect on self-esteem beyond commonly defined posttraumatic growth. Journal of Adolescence, 44, 224-231. https://doi.org/10.1016/j.adolescence.2015.08.001.

Tedeschi, R. G., \& Calhoun, L. G. (1996). The Posttraumatic Growth Inventory: measuring the positive legacy of trauma. Journal of Traumatic Stress, 9(3), 455-472. https://doi.org/10.1002/jts. 2490090305.

Titzmann, P. F. (2012). Growing up too soon? Parentification among immigrant and native adolescents in Germany. Journal of Youth and Adolescence, 41(7), 880-893. https://doi.org/10.1007/ s10964-011-9711-1.

Tomeny, T. S., Barry, T. D., Fair, E. C., \& Riley, R. (2016). Parentification of adult siblings of individuals with Autism Spectrum Disorder. Journal of Child and Family Studies, 26(4), 1056-1067. https://doi.org/10.3109/13668250.2016.1248376.

Walker, J. P., \& Lee, R. E. (1998). Uncovering strengths of children of alcoholic parents. Contemporary Family Therapy, 20(4), 521-538. https://doi.org/10.1023/A:1021684317493.

Wells, M., Glickauf-Hughes, C., \& Jones, R. (1999). Codependency: a grassroots construct's relationship to shame-proneness, lower selfesteem, and childhood parentification. American Journal of Family Therapy, 27(1), 63-71. https://doi.org/10.1080/019261899262104.

Wells, M., \& Jones, R. (2000). Childhood parentification and shameproneness: a preliminary study. American Journal of Family Therapy, 28(1), 19-27. https://doi.org/10.1080/019261800261789.

Williams, K., \& Francis, S. E. (2010). Parentification and psychological adjustment: locus of control as a moderating variable. Contemporary Family Therapy, 32(3), 231-237. https://doi.org/ 10.1007/s10591-010-9123-5.

Winnicott, D. W. (1958). Through paediatrics to psychoanalysis: Collected papers. London: Karnac.

Wojciszke, B. (2002). Człowiek wśród ludzi. Zarys psychologii spotecznej [A man among people. Outline of social psychology]. Warszawa: Wydawnictwo Naukowe Scholar.

Yeh, H. C., \& Lempers, J. D. (2004). Perceived sibling relationships and adolescent development. Journal of Youth and Adolescence, 33(2), 133-147. https://doi.org/10.1023/B:JOYO.0000013425. 86424.0f. 